\title{
Evaluation of wheat or corn dried distillers' grains with solubles on performance and carcass characteristics of feedlot steers
}

\author{
L. J. Walter ${ }^{1}$, J. L. Aalhus ${ }^{2}$, W. M. Robertson², T. A. McAllister ${ }^{3}$, D. J. Gibb \\ M. E. R. Dugan ${ }^{2}$, N. Aldai ${ }^{2}$, and J. J. McKinnon ${ }^{1,4}$ \\ ${ }^{1}$ Department of Animal and Poultry Science, University of Saskatchewan, Saskatoon, Saskatchewan, Canada S7H \\ 5A8; ${ }^{2}$ Agriculture and Agri-Food Canada, Lacombe Research Centre, Lacombe, Alberta, Canada T4L 1W1; and \\ ${ }^{3}$ Agriculture and Agri-Food Canada, Lethbridge Research Centre, Lethbridge, Alberta, Canada T1J 4B1. \\ Received 29 September 2009, accepted 12 January 2010.
}

\begin{abstract}
Walter, L. J., Aalhus, J. L., Robertson, W. M., McAllister, T. A., Gibb, D. J., Dugan, M. E. R. and McKinnon, J. J. 2010. Evaluation of wheat or corn dried distillers' grains with solubles on performance and carcass characteristics of feedlot steers. Can. J. Anim. Sci. 90: $259-269$. A study was conducted on crossbred steers $(n=275 ; 376 \pm 24 \mathrm{~kg})$ to evaluate performance and carcass quality of cattle fed wheat or corn dried distillers' grains with solubles (DDGS). The control ration contained $86.6 \%$ rolled barley grain, $5.7 \%$ supplement and $7.7 \%$ barley silage (DM basis). The four treatments included replacement of barley grain at 20 or $40 \%$ of the diet (DM basis) with wheat or corn DDGS. Steers were slaughtered at a common end weight of $645 \mathrm{~kg}$ with 100 steers randomly $(n=20$ per treatment) selected for determination of the retail yield of sub-primal boneless boxed beef (SPBBB). Data were analyzed as a completely randomized design using pen as the experimental unit. Feeding increasing levels of wheat DDGS led to a quadratic increase in dry matter intake $(\mathrm{DMI})(P<0.01)$, whereas increasing levels of corn DDGS led to a quadratic decrease in DMI $(P=0.01)$. Average daily gain was not influenced $(P=0.13)$ by feeding wheat or corn DDGS, but cattle fed corn DDGS exhibited a quadratic increase $(P=0.01)$ in gain:feed. As a result, a quadratic increase $(P<0.01)$ in calculated $\mathrm{NE}_{\mathrm{g}}$ of the diet was observed as corn DDGS levels increased. A linear decrease $(P=0.04)$ in days on feed $(169,166$ and $154 \mathrm{~d})$ was noted when increasing levels of wheat DDGS $(0,20$ and $40 \%)$ were fed. Dressing percentage increased in a linear fashion with wheat DDGS $(P<0.01)$ inclusion level and in a quadratic fashion $(P=0.01)$ as corn DDGS inclusion level increased although other carcass traits were not affected $(P>0.10)$ by treatment. The results indicate that replacement of barley grain with corn or wheat DDGS up to $40 \%$ of the diet (DM) can lead to superior performance (improved gain:feed or reduced days on feed, respectively) with no detrimental effect on quality grade or carcass SPBBB yield.
\end{abstract}

Key words: Dried distillers' grains with solubles, corn, wheat, feedlot performance, carcass quality, steers

Walter, L. J., Aalhus, J. L., Robertson, W. M., McAllister, T. A., Gibb, D. J., Dugan, M. E. R. et McKinnon, J. J. 2010. Incidence des extraits solubles secs de distillerie de blé ou de maïs sur le rendement et les paramètres de la carcasse des bouvillons d'engrais. Can. J. Anim. Sci. 90: 259-269. Les auteurs ont effectué une étude sur des bouvillons hybrides $(n=275 ; 376 \pm 24 \mathrm{~kg})$ en vue d'évaluer le rendement et la qualité de la carcasse des animaux engraissés avec des extraits solubles secs de distillerie (ESSD) de blé ou de maïs. La ration témoin contenait 86,6\% de flocons d'orge, $5,7 \%$ de supplément et 7,7\% d'ensilage d'orge (matière sèche). Les quatre traitements incluaient la substitution de $20 \%$ ou de $40 \%$ d'orge (matière sèche) par des ESSD de blé ou de maïs. Les animaux ont été sacrifiés quand leur poids atteignait $645 \mathrm{~kg}$ et on en a sélectionné une centaine au hasard $(n=20$ par traitement) pour déterminer le rendement au détail de bœuf de coupe secondaire désossé en caisse carton (BCSDCC). Les données ont été analysées comme si elles émanaient d'un essai complètement randomisé ayant l'enclos pour unité expérimentale. La concentration croissante d'ESSD de blé

${ }^{4}$ To whom correspondence should be addressed (e-mail: john.mckinnon@usask.ca).
Abbreviations: ADF, acid detergent fibre; ADG, average daily gain; ADIN, acid detergent insoluble nitrogen; CP, crude protein; DDGS, dried distillers' grains with solubles; DM, dry matter; DMI, dry matter intake; EE, ether extract; feed efficiency, kg gain:kg feed; HCW, hot carcass weight; US, ultrasound; l. thoracis, longissimus thoracis; NDF, neutral detergent fibre; NDIN, neutral detergent insoluble nitrogen; NEm, net energy maintenance; $\mathbf{N E g}$, net energy gain; SD, standard deviation; SE, standard error; SEP, standard error of prediction; SC, subcutaneous; SPBBB, sub-primal boneless boxed beef; WDGS, wet distillers' grains with solubles 
entraîne une augmentation quadratique de l'ingestion de matière sèche (IMS) $(P<0,01)$, tandis que la hausse de la concentration d'ESSD de maïs donne lieu à une diminution quadratique de l'IMS $(P=0,01)$. Les ESSD de blé ou de maïs n'ont aucune incidence sur le gain quotidien moyen $(P=0,13)$, mais les animaux recevant des ESSD de maïs affichaient une hausse quadratique $(P=0,01)$ du rapport gain:aliment. C'est pourquoi les auteurs ont noté une hausse quadratique $(P<0,01)$ du gain d'énergie nette calculé pour la ration quand la concentration d'ESSD de maïs augmente. Le nombre de jours d'engraissement diminue $(P=0,04)$ linéairement $(169,166$ et 154 jours $)$ quand la proportion d'ESSD de blé augmente $(0,20$ et $40 \%)$. Le rendement à l'abattage s'accroît linéairement avec la proportion d'ESSD de blé $(P<0,01)$ et de manière quadratique $(P=0,01)$ avec celle d'ESSD de maïs, bien que le traitement n'affecte pas les autres paramètres de la carcasse $(P>0,10)$. Ces résultats indiquent qu'en substituant jusqu'à $40 \%$ de l'orge de la ration (matière sèche) par des ESSD de maïs ou de blé, on pourrait obtenir une meilleure performance, hausse du rapport gain:aliment ou réduction du nombre de jours d'engraissement, respectivement), sans que la qualité ou le rendement en BCSDCC de la carcasse en souffre.

Mots clés: Extraits solubles secs de distillerie, maïs, blé, rendement à l'engrais, qualité de la carcasse, bouvillons

The growth of the ethanol industry has resulted in large increases in the supply and use of dried distillers' grains with solubles (DDGS) in livestock rations. With regards to feedlot cattle, there has been a significant amount of research on the feeding value of corn-based DDGS as both a protein and energy source, and its associated effects on carcass traits (Ham et al. 1994; Klopfenstein et al. 2008). In terms of the energy value of corn distillers' grains with solubles, Larson et al. (1993) observed that wet distillers' grains with solubles (WDGS) when fed at levels ranging from 5.2 to $40 \%$ of DM averaged 2.53 and $1.96 \mathrm{Mcal} \mathrm{kg}{ }^{-1} \mathrm{NE}_{\mathrm{g}}$, when fed to yearlings and calves, respectively. These values averaged 169 and $128 \%$ the $\mathrm{NE}_{\mathrm{g}}$ value of dry rolled corn. Ham et al. (1994) reported that corn WDGS and DDGS fed at $40 \%$ of the ration resulted in $\mathrm{NE}_{\mathrm{g}}$ values of 2.16 and $1.87 \mathrm{Mcal} \mathrm{kg}^{-1}$, respectively, an increase of 39 and $21 \%$ relative to corn grain. In finishing rations, corn DDGS has been successfully fed up to $40 \%$ of dietary DM; however, recent studies have suggested that inclusion at 20 to $25 \%$ of the ration DM is optimal for finishing cattle (Benson et al. 2005; Buckner et al. 2008).

Relative to corn DDGS, there have been relatively few studies that have examined the feeding value of wheat DDGS. Boila and Ingalls (1994) examined the digestibility of wheat DDGS and concluded that wheat DDGS is a good source of rumen bypass protein (63.5\%, ruminally undegraded nitrogen). With respect to the inclusion of wheat DDGS as an energy source ( $>15 \%$ of diet DM), the replacement of rolled barley with wheat DDGS at 25 and $50 \%$ of the ration in backgrounding diets increased ADG and improved feed efficiency (McKinnon and Walker 2008). Diet $\mathrm{NE}_{\mathrm{g}}$ was $8.2 \%$ higher in diets supplemented with DDGS relative to the control barley-based diet (McKinnon and Walker 2008). Beliveau and McKinnon (2008) found no effect on ADG, feed efficiency or DMI with the substitution of up to $23 \%$ wheat DDGS for rolled barley in the finishing rations. Gibb et al. (2008) observed that finishing cattle fed wheat DDGS up to $60 \%$ of the diet had linear increases in DMI, similar ADG and subsequently poorer feed efficiency as wheat DDGS inclusion rate increased.
With respect to carcass quality, cattle fed corn DDGS have been shown to have reduced marbling scores, particularly when fed at levels greater than $23 \%$ of the diet (Reinhardt et al. 2007). Klopfenstein et al. (2008) using meta analysis of several studies, reported a linear increase in yield grades and a trend for a linear decrease in marbling scores when corn DDGS comprised $40 \%$ of the diet DM. In contrast, studies with wheat DDGS have not reported any adverse effects on carcass quality (Beliveau and McKinnon 2008) other than a quadratic increase in subcutaneous fat thickness (Gibb et al. 2008).

As the supply of both wheat and corn DDGS increases, there is potential for these two byproducts to compete as feedstuffs. To date, there has been no direct evaluation of the relative feeding value of these feeds in finishing cattle diets. Therefore, the objectives of this trial were to evaluate the performance and carcass quality of steers fed wheat DDGS relative to those of cattle fed corn DDGS in feedlot finishing rations.

\section{MATERIALS AND METHODS}

\section{Animals, Housing and Experimental Design}

All cattle utilized in this study were cared for under Canadian Council of Animal Care guidelines (CCAC 1993). Two hundred and seventy-five crossbred steers were purchased, and shipped to the Beef Cattle Research Station at the University of Saskatchewan. Upon arrival, all steers were tagged and treated for internal and external parasites with Ivomec ${ }^{\mathrm{TM}}$ (Merial Canada Inc., Baie d'Urfé, QC). The cattle were vaccinated against clostridial diseases with Covexin $8^{\mathrm{TM}}$ (ScheringPlough, Kirkland, QC), Pasteurella haemolytica and Haemophilus somnus with Somnu-Star $\mathrm{Ph}^{\mathrm{TM}}$ (Novartis, Mississauga, ON) and infectious bovine rhinotracheitis, bovine viral diarrhea (types 1 and 2), Parainfluenza 3 virus, and bovine respiratory syncytial virus with Biostar, Starvac 4 Plus $^{\mathrm{TM}}$ (Novartis, Mississauga, ON). All cattle were fed a barley-based backgrounding ration $(38.3 \%$ barley silage, $30.2 \%$ grass hay, $23.7 \%$ rolled barley grain and $7.8 \%$ supplement, DM basis) from arrival to the start of the trial. One animal was removed from the trial due to physical injury unrelated to treatment. 
Steers were weighed $(376 \pm 24 \mathrm{~kg}$, mean \pm SD) and implanted with Synovex Choice ${ }^{\mathrm{TM}}$ (Wyeth Animal Health, Guelph, ON) at the start of the finishing trial. The steers were randomly assigned to 1 of 25 outdoor pens with each pen randomly assigned to one of five treatments in a completely randomized design. The trial had a target end-point of $645 \mathrm{~kg}$ liveweight (unshrunk basis). When individual animals in a pen reached this end-point, they were weighed and sent for slaughter, generally within a week of being taken off test.

\section{Treatments and Dietary Composition}

At the start of the trial, an eight-step diet adaptation was used to adapt the steers over a 21-d period from the backgrounding diet to the final finishing rations. The control diet was composed of $86.6 \%$ rolled barley grain, $5.7 \%$ supplement and $7.7 \%$ barley silage (DM basis) (Table 1) and was formulated to contain $12 \% \mathrm{CP}$ and 1.95 and $1.30 \mathrm{Mcal} \mathrm{kg}^{-1} \mathrm{NE}_{\mathrm{m}}$ and $\mathrm{NE}_{\mathrm{g}}$, respectively. The four treatments included replacement of barley grain with 20 or $40 \%$ wheat or corn DDGS (DM basis) (Table 1). Rations were formulated to meet or exceed National Research Council requirements (NRC 2000) for $\mathrm{CP}$, trace minerals and fat-soluble vitamins (Table 1). The Ca:P ratio was formulated to range from 1.5:1 to 2:1 with limestone added to the supplement as the DDGS content of the ration increased.
Monensin sodium was fed at $27 \mathrm{mg} \mathrm{kg}^{-1}$ (DM basis) (Elanco Animal Health, Guelph, ON) in all diets.

The barley silage (AC Rosser) used in the study was grown at the University of Saskatchewan, harvested and stored in plastic bags (Ag-Bag, Miller-St. Nazianz, Inc., St Naziance, WI). Barley silage samples were taken every 2 wk with the dry matter (DM) content recorded and used to adjust daily feeding amounts as necessary. Barley grain $\left(61.1 \pm 2.1 \mathrm{~kg} \mathrm{hL}^{-1}\right.$, mean $\left.\pm \mathrm{SD}\right)$ was purchased from commercial grain sources and dry rolled on site (RossKamp Champion, Waterloo, IA). The wheat DDGS was supplied by Noramera BioEnergy Corporation (Weyburn, SK) while the corn DDGS was purchased from ConAgra Foods (Omaha, NE). Bunk samples of the total mixed ration were collected every 2 wk from each pen, while barley, DDGS (wheat and corn) and supplement samples were taken as each load was received.

\section{Data Collection and Analysis}

Cattle were fed for ad libitum intake with feed being delivered twice daily in two equal allotments. The amount of feed delivered to each pen was recorded daily. Every $2 \mathrm{wk}$, the bunks were cleaned, and any orts were weighed and discarded. Actual dry matter intakes for the pen were calculated based on the dry matter delivered to the bunk and corrected for any orts that were recorded every $2 \mathrm{wk}$. Animals were weighed

\begin{tabular}{|c|c|c|c|c|c|}
\hline & \multicolumn{5}{|c|}{ Treatment } \\
\hline & Control & $20 \%$ wheat DDGS & $40 \%$ wheat DDGS & $20 \%$ corn DDGS & $40 \%$ corn DDGS \\
\hline \multicolumn{6}{|l|}{ Diet composition (\% DM basis) } \\
\hline Barley silage & 7.7 & 7.6 & 7.5 & 7.6 & 7.6 \\
\hline Barley grain & 86.6 & 66.3 & 47.1 & 66.4 & 47.2 \\
\hline Wheat DDGS & 0.0 & 20.4 & 39.7 & 0.0 & 0.0 \\
\hline Corn DDGS & 0.0 & 0.0 & 0.0 & 20.3 & 39.5 \\
\hline Supplement & 5.7 & 5.7 & 5.7 & 5.7 & 5.7 \\
\hline \multicolumn{6}{|c|}{ Supplement composition (\% DM basis) } \\
\hline Barley & 13.3 & 44.4 & 38.4 & 44.4 & 38.4 \\
\hline Canola meal & 36.6 & 0.0 & 0.0 & 0.0 & 0.0 \\
\hline Limestone & 21.8 & 30.4 & 36.6 & 30.4 & 36.6 \\
\hline Vitamin premix ${ }^{\mathrm{z}}$ & 10.6 & 10.5 & 10.4 & 10.5 & 10.4 \\
\hline Ionophore premix ${ }^{y}$ & 7.7 & 7.6 & 7.6 & 7.6 & 7.6 \\
\hline Trace mineral salt ${ }^{\mathrm{x}}$ & 7.1 & 7.1 & 7.0 & 7.1 & 7.0 \\
\hline Canola oil & 1.9 & - & - & - & - \\
\hline Urea & 1.0 & - & - & - & - \\
\hline \multicolumn{6}{|l|}{ Ration analysis (\% DM basis) $)^{w}$} \\
\hline Crude protein $(\mathrm{CP})$ & $12.1 \pm 0.22$ & $15.8 \pm 0.32$ & $20.9 \pm 0.37$ & $15.2 \pm 0.14$ & $18.3 \pm 0.13$ \\
\hline Ether extract (EE) & $2.0 \pm 0.07$ & $2.1 \pm 0.06$ & $2.5 \pm 0.06$ & $3.8 \pm 0.09$ & $6.2 \pm 0.12$ \\
\hline Acid detergent fiber (ADF) & $7.9 \pm 0.60$ & $9.3 \pm 0.48$ & $12.2 \pm 0.62$ & $9.2 \pm 0.45$ & $11.3 \pm 0.59$ \\
\hline Neutral detergent fiber (NDF) & $22.5 \pm 0.96$ & $23.6 \pm 0.95$ & $25.0 \pm 0.90$ & $24.2 \pm 0.68$ & $26.8 \pm 0.61$ \\
\hline Calcium $(\mathrm{Ca})$ & $0.6 \pm 0.03$ & $0.7 \pm 0.06$ & $1.0 \pm 0.05$ & $0.7 \pm 0.42$ & $0.8 \pm 0.04$ \\
\hline Phosphorus (P) & $0.4 \pm 0.01$ & $0.5 \pm 0.01$ & $0.6 \pm 0.02$ & $0.5 \pm 0.01$ & $0.6 \pm 0.01$ \\
\hline
\end{tabular}

${ }^{\mathbf{z}}$ University of Saskatchewan vitamin A and D supplement $=440500 \mathrm{IU}$ vitamin A, and $88000 \mathrm{IU}$ vitamin $\mathrm{D}_{3} \mathrm{~kg}^{-1}$.

${ }^{\mathbf{y}}$ University of Saskatchewan Feed Unit Ionophore Premix: Contains $96.77 \%$ barley and $3.23 \%$ Rumensin ${ }^{\circledR}$ Premix containing monensin (as monensin sodium) at $200 \mathrm{~g} \mathrm{~kg}^{-1}$ (Elanco, Guelph, ON) (DM basis).

${ }^{\mathbf{x}}$ Trace mineral salt: 95\% NaCl, 12000 ppm Zn, 10000 ppm Mn, 4000 ppm Cu, 400 ppm I, 60 ppm Co, 30 ppm Se.

"Values shown with standard error. 
every $2 \mathrm{wk}$, prior to the morning feeding. Ultrasound subcutaneous fat (USFAT) measurements were taken every $4 \mathrm{wk}$ in conjunction with a weigh day according to the procedure of Bergen et al. (1997) using an Aloka 500 $\mathrm{V}$ real-time ultrasound machine and a $17-\mathrm{cm}$ linear array transducer. As the steers approached their target end weight, USFAT were taken every 2 wk in accordance with weigh days. Ultrasound longissimus thoracis (USLT) measurements were taken at the start and end of the trial to calculate longissimus thoracis area gain. Net energy content of the diet was calculated according to Zinn and Shen (1998) as outlined by McKinnon and Walker (2008).

One hundred and seventy-four of the steers were slaughtered at XL Beef Inc. in Moose Jaw, SK. The cattle were sent to slaughter in eight loads over the period 2008 Apr. 18 to Jul. 28, once they had obtained the target weight of $645 \mathrm{~kg}$. The steers were shipped the day prior to the kill date and held overnight in lairage. Hot carcass weight $(\mathrm{HCW})$ was obtained immediately after slaughter. After $24 \mathrm{~h}$, carcasses were knife ribbed between the 12th and 13th ribs and carcass data (subcutaneous fat thickness, marbling score, 1. thoracis area, estimated lean yield and any off-grades) were collected by Canadian Beef Grading Agency graders. Marbling scores were based on a 10-point system with $1=$ very abundant, $5=$ moderate, $7=$ small and $10=$ devoid. Liver abscess scores were subjectively measured using the Elanco classification system, as modified by McKinnon et al. (1992).

A subset of the steers $(n=100)$ was slaughtered at the Agriculture and Agri-Food Canada Lacombe Meat Research Centre (Lacombe, AB). The steers were shipped in five groups of 20 with four steers per treatment per load (one load per week over the period 2008 May 23 to Jun. 27). Cattle for each load were selected based on proximity to the target slaughter weight in a similar manner to the cattle slaughtered at the commercial packing plant. Each load was shipped the day prior to the kill day and held overnight in lairage. Hot carcass weights were recorded during the dressing procedure. Carcasses were chilled for $24 \mathrm{~h}$ after which Canadian Beef Grading Agency Graders collected carcass data as per the protocol used for the commercial slaughter. Carcass front and hind weights were determined by separating the left side of the carcass at the level of the grade site between the rib and loin sections. Both the front $(24 \mathrm{~h}$ postmortem) and hind $(48 \mathrm{~h}$ postmortem) quarters of the left side of each carcass were partitioned into SPBBB and waste (fat and bone). The SPBBB was trimmed according to the Canadian Meat Council (2000) with the edible trim partitioned to 65 or $85 \%$ lean. To determine the fat content of the trim piles, the trim piles were each ground three times (Butcher Boy Meat Grinder Model TCA22 with a 3.18-mm grind plate, Lasar Manufacturing Co., Ayrshire, UK), mixed thoroughly, and a 100 -g sub-sample was dried in a mechanical convection oven (VWR
Scientific Model $1370 \mathrm{FM}$, Mississauga, ON) at $105^{\circ} \mathrm{C}$ for $24 \mathrm{~h}$ to determine moisture content. Free oil in the dried sample was decanted and weighed. The remaining dried product was pulverized and two 4-g sub-samples were extracted in petroleum ether using a Tecator Soxtec Extraction System Model 2050 (Foss Analytical AB, Hoganas, Sweden). Total crude fat in the sample was determined as the weight of the oil decanted plus the percentage of fat in the dried sample. Once the total crude fat analysis was recorded, lean trim was adjusted to the appropriate fat content ( 65 or $85 \%$ ) by the addition or removal of extracted fat.

\section{Chemical Analysis}

All forage and bunk samples were dried in a forced-air oven at $55^{\circ} \mathrm{C}$ for $72 \mathrm{~h}$. Dried forage samples were ground through a hammer mill fitted with a $1-\mathrm{mm}$ screen (Christy \& Norris 8" Lab Mill, Christy Turner Ltd. Chelmsford, UK). Bunk samples were dried on a pen basis and composited by treatment for each 2 -wk collection period. Bunk and concentrate samples were ground through a 1-mm screen using a Retsch ZM100 grinder (Haan, Germany). Composite total mixed ration samples were analyzed in duplicate according to the Association of Official Analytical Chemists (2000) for $\mathrm{DM}$ by drying at $135^{\circ} \mathrm{C}$ (AOAC method 930.15), CP (AOAC method 948.13), NDF treated with amylase and without the addition of sodium sulphite (AOAC method 2002.04), ADF (AOAC method 973.18) and ether extract (AOAC method 920.39). Calcium and phosphorus were analyzed using the dry ashing procedure (AOAC methods 927.02 and 965.17, respectively). Calcium was determined using an atomic absorption spectrophotometer (Perkin-Elmer, Model 2380, CT), while phosphorus was read at $410 \mathrm{~nm}$ on a spectrometer (Pharmacia, LKB-Ultraspec III, Stockholm, Sweden).

Each batch of wheat $(n=2)$ and corn $(n=2)$ DDGS were analyzed by Cumberland Valley Analytical Services (CVAS, Hagerstown, MD) according to the Association of Official Analytical Chemists (2000). Samples were analyzed for DM by drying at $135^{\circ} \mathrm{C}$ (AOAC method 930.15), CP (AOAC method 990.03) using a Leco FP-528 Nitrogen Combustion Analyzer (Leco, St Joseph, MI), ADF (AOAC method 973.18), ADIN (using ADF residue and Leco FP-528 Nitrogen Combustion Analyzer, Leco, St Joseph, MI), ash (AOAC method 942.05) and fat using a tecator extraction unit (AOAC method 2003.05). The methods of Van Soest et al. (1991) were used to analyze NDF content and the NDF residue was used for NDIN analysis (Leco FP-528 Nitrogen Combustion Analyzer, Leco, St Joseph, MI).

\section{Statistical Analysis}

Data were analyzed as a completely randomized design, with pen as the experimental unit and treatment as a fixed effect using the Mixed Model procedure of SAS (Version 9.1; SAS Institute, Inc. Cary, NC). Denominator degrees 
of freedom were determined using the Kenward-Roger option which uses the Satterthwaite adjustment. Results were analyzed using a protected F-test $(P<0.05)$. Polynomial contrasts were used to determine the linear and quadratic effects of wheat or corn DDGS inclusion rate. Significant results $(P \leq 0.05)$ were presented using slope (linear) or local maxima/minima (quadratic) for the best fit polynomial regression equation. Marbling and liver abscess score data were analyzed using the GLIMMIX macro (SAS, Version 9.1; SAS Institute, Inc. Cary, NC) with a binomial error structure and logit data transformation.

\section{RESULTS AND DISCUSSION}

The wheat DDGS utilized in this study averaged 39.3 $\pm 1.2 \%$ CP, $3.9 \pm 0.4 \%$ EE, $41.4 \pm 0.9 \%$ NDF, 16.6 $\pm 3.5 \%$ ADF, $23.6 \pm 2.0 \%$ ADIN ( $\% \mathrm{~N}), 0.12 \pm 0.01 \%$ $\mathrm{Ca}$ and $0.97 \pm 0.12 \% \mathrm{P}($ mean $\pm \mathrm{SE}, \mathrm{DM})$. The CP, EE and NDF values for the wheat DDGS were similar to that previously reported (Beliveau and McKinnon 2008; McKinnon and Walker 2008). The ADF level in the wheat DDGS used in this study was higher than that reported by Beliveau and McKinnon (2008) (13.2\%), but similar to Gibb et al. (2008) (19.5\%). The ADIN content was considerably higher than that reported by Beliveau and McKinnon (2008) $(10.5 \% \mathrm{~N})$ and Gibb et al. (2008) $(10.5 \% \mathrm{~N})$. The high ADIN value of the wheat DDGS could reduce the nitrogen digestibility of the diet, although Nakamura et al. (1994) found a poor correlation between ADIN levels of DDGS and $\mathrm{N}$ digestibility. Furthermore, Kleinschmidt et al. (2006) found no change in the feed efficiency of dairy cows fed a high $\operatorname{ADIN}(23.1 \% \mathrm{~N})$ corn DDGS relative to those fed a low ADIN (9.4 and 10.3\% N) corn DDGS.

The corn DDGS fed in this study averaged 31.8 $\pm 0.1 \% \mathrm{CP}, 13.7 \pm 0.7 \%$ EE, $43.8 \pm 0.5 \% \mathrm{NDF}, 11.5$ $\pm 0.2 \%$ ADF, $11.6 \pm 0.1 \%$ ADIN ( $\%$ N), $0.03 \pm 0.01 \%$ $\mathrm{Ca}$ and $0.89 \pm 0.01 \% \mathrm{P}$ (mean $\pm \mathrm{SE}, \% \mathrm{DM})$. The $\mathrm{CP}$ and NDF levels for the corn DDGS are comparable to previous findings (Spiehs et al. 2002). However, the ADF levels are somewhat lower than those reported by Spiehs et al. (2002) (13.8 to $18.5 \%$ ) and Kleinschmidt (2007) (14.7 to $20.3 \%$ ). The EE value for corn DDGS was slightly higher than previous reports of 10 to $12 \%$ by Spiehs et al. (2002), but comparable to the $13.9 \%$ reported by Gunn et al. (2009).

Substituting wheat or corn DDGS at 20 and $40 \%$ of the ration (DM basis) for barley increased $\mathrm{CP}$ content of the diets from $12.1 \%$ in the control diet to 15.8 and $20.9 \%$ in the 20 and $40 \%$ wheat DDGS diets and 15.2 and $18.3 \%$ for the 20 and $40 \%$ corn DDGS diets, respectively. In agreement with other studies (Benson et al. 2005; Beliveau and McKinnon 2008) ADF, NDF and $P$ values (Table 1) increased with increasing level of wheat and corn DDGS in the diet. The EE content of the diet increased substantially with the addition of corn DDGS $(2.0 \%$ in the control diet vs. 3.8 and $6.2 \%$ in the 20 and $40 \%$ corn DDGS rations, respectively). The EE content of the diet was not affected greatly by the inclusion of wheat DDGS (2.1 and $2.5 \%$ in the 20 and $40 \%$ rations, respectively).

\section{Finishing Performance}

Dry matter intake showed a differential response for cattle fed wheat or corn DDGS (Table 2). DMI increased $(P<0.01)$ in a quadratic fashion $(y=10.358-$ $0.027 x+0.001 x^{2} R^{2}=0.73$ SEP 0.212$)$ as wheat DDGS increased in the ration while DMI decreased $(P=0.01)$ in a quadratic fashion $\left(y=10.358+0.027 x-0.002 x^{2}\right.$ $R^{2}=0.88$ SEP 0.295 ) with increased corn DDGS levels. Solving the equation for wheat DDGS gives a local minima for DMI at a $13 \%$ inclusion rate with intake increasing as wheat DDGS increases to the $40 \%$ inclusion level. Beliveau and McKinnon (2008) noted a similar response to the current trial with cattle fed wheat DDGS up to $32 \%$ (DM) in a backgrounding trial. In contrast, these authors found no effect of wheat DDGS (up to $23 \%$ of the diet, DM) on DMI in finishing cattle. Gibb et al. (2008) observed a linear increase in DMI as wheat DDGS increased to $60 \%$ of the ration DM. These workers hypothesized that the increase in DMI was a compensatory response to a reduction in digestibility with increasing wheat DDGS as digestibility of the diet was reduced by $9.8 \%$ when wheat DDGS comprised $60 \%$ of diet DM.

There was no treatment effect $(P=0.13)$ on ADG, although, numerically, cattle fed $40 \%$ wheat DDGS had the highest ADG (Table 2). This lack of significance is somewhat surprising as these cattle consumed more feed than the control cattle. However, calculated $\mathrm{NE}_{\mathrm{g}}$ based on performance was not different $(P>0.05)$ between the control diet and the two wheat DDGS diets. Cattle fed wheat DDGS exhibited a linear decrease $(P=0.04)$ in days on feed $\left(y=170.63-0.375 x R^{2}=0.43\right.$ SEP 7.59) as concentration of wheat DDGS increased in the diet. This is likely a reflection of the increased DMI $(P<0.01)$ and numerically higher ADG of the wheat DDGS fed steers, particularly those fed $40 \%$ wheat DDGS. The intake and ADG responses of the wheat DDGS fed cattle also explains why there was no effect of wheat DDGS inclusion level on gain:feed (Table 2). Beliveau and McKinnon (2008) reported similar results for ADG and gain:feed for finishing cattle fed up to $23 \%$ wheat DDGS. Gibb et al. (2008) found that DMI increased linearly with increasing levels of wheat DDGS in the diet (up to 60\%) with no effect on ADG. As a result, these workers reported that gain:feed ratios decreased with increasing levels of wheat DDGS.

In contrast, cattle fed corn DDGS exhibited a quadratic decrease $(P=0.01)$ in DMI as inclusion levels increased (Table 2). Solving the quadratic equation gives a local maxima for DMI at the $8.0 \%$ corn DDGS inclusion level. Eun et al. (2009) also found that replacing rolled barley with corn DDGS (up to $18.3 \%$, DM) in finishing rations resulted in reduced DMI, with the lowest DMI at the highest DDGS inclusion level. 


$$
\text { סे }
$$

\begin{tabular}{|c|c|c|c|c|c|c|c|c|c|c|c|}
\hline & \multicolumn{5}{|c|}{ Dietary treatment } & \multirow[b]{2}{*}{ PSEM $^{z}$} & \multirow[b]{2}{*}{$\begin{array}{l}P \text { value } \\
\text { treatment }\end{array}$} & \multicolumn{4}{|c|}{$P$ value contrast } \\
\hline & Control & $\begin{array}{l}20 \% \text { wheat } \\
\text { DDGS }\end{array}$ & $\begin{array}{l}40 \% \text { wheat } \\
\text { DDGS }\end{array}$ & $\begin{array}{l}20 \% \text { corn } \\
\text { DDGS }\end{array}$ & $\begin{array}{l}40 \% \text { corn } \\
\text { DDGS }\end{array}$ & & & $\begin{array}{l}\text { Linear } \\
\text { wheat }\end{array}$ & $\begin{array}{l}\text { Quadratic } \\
\text { wheat }\end{array}$ & $\begin{array}{l}\text { Linear } \\
\text { corn }\end{array}$ & $\begin{array}{l}\text { Quadratic } \\
\text { corn }\end{array}$ \\
\hline Start of trial weight (kg) & 375 & 376 & 377 & 376 & 376 & 0.80 & 0.70 & & & & \\
\hline End of trial weight (kg) & 654 & 649 & 648 & 652 & 653 & 2.28 & 0.34 & & & & \\
\hline $\begin{array}{l}\text { Average daily gain } \\
\left(\mathrm{kg} \mathrm{d}^{-1}\right)\end{array}$ & 1.62 & 1.63 & 1.73 & 1.66 & 1.68 & 0.03 & 0.13 & & & & \\
\hline $\begin{array}{l}\text { Dry matter intake } \\
\qquad\left(\mathrm{kg} \mathrm{d}^{-1}\right)\end{array}$ & 10.4 & 10.2 & 10.9 & 10.2 & 8.8 & 0.11 & $<0.01$ & 0.02 & $<0.01$ & $<0.01$ & 0.01 \\
\hline Gain:Feed & 0.156 & 0.159 & 0.158 & 0.163 & 0.192 & 0.002 & $<0.01$ & 0.65 & 0.52 & $<0.01$ & 0.01 \\
\hline $\mathrm{NE}_{\mathrm{g}}$ of diet $(\mathrm{MCal} \mathrm{kg}-1)$ & 1.27 & 1.30 & 1.26 & 1.32 & 1.58 & 0.02 & $<0.01$ & 0.41 & 0.11 & $<0.01$ & $<0.01$ \\
\hline Days on feed & 169 & 166 & 154 & 163 & 162 & 3.26 & 0.049 & 0.04 & 0.37 & 0.12 & 0.46 \\
\hline \multicolumn{12}{|l|}{ US backfat thickness $(\mathrm{mm})^{y}$} \\
\hline Start of test & 2.2 & 2.2 & 2.6 & 2.2 & 2.0 & 0.24 & 0.51 & & & & \\
\hline End of test & 8.4 & 8.8 & 9.8 & 9.0 & 9.2 & 0.51 & 0.41 & & & & \\
\hline Gain & 6.2 & 6.8 & 7.4 & 7.0 & 7.0 & 0.46 & 0.47 & & & & \\
\hline \multicolumn{12}{|c|}{ US longissimus thoracis area $\left(\mathrm{cm}^{2}\right)^{x}$} \\
\hline Start of test & 59.0 & 59.8 & 58.6 & 58.8 & 59.4 & 0.55 & 0.56 & & & & \\
\hline End of Test & 89.4 & 90.6 & 89.4 & 91.8 & 89.2 & 1.10 & 0.42 & & & & \\
\hline Gain & 31.0 & 30.6 & 30.8 & 33.6 & 29.8 & 1.39 & 0.39 & & & & \\
\hline
\end{tabular}

${ }^{\mathrm{z}} \mathrm{PSEM}=$ pooled standard error of the mean.

${ }^{\mathrm{y}}$ Ultrasound measurements of subcutaneous fat thickness.

${ }^{\mathrm{x}}$ Ultrasound measurements of longissimus thoracis area. 
The decrease in DMI associated with feeding corn DDGS in barley rations could be due to the increasing dietary fat level associated with diets that contain corn DDGS. Dietary fat levels in this study reached $6.2 \pm 0.12 \%$ on the $40 \%$ corn DDGS diet (Table 1). Zinn and Jorquera (2007) recommended a maximum dietary fat intake of 6 to $7 \%$ in high concentrate rations to prevent DMI depression. Allen et al. (2009) suggests that elevated serum fatty acid concentrations, particularly unsaturated fatty acids, may have a satiety effect in accordance with the hepatic oxidation theory. This theory states that food intake is controlled by the hypothamus, which, in turn, is alerted to the body's energy status by the degree of hepatic oxidation of a variety of metabolic fuels. However, this theory does not explain why DMI is not reduced when corn DDGS is fed in corn-based rations. For example, Buckner et al. (2008) did not find any effect on DMI when corn DDGS replaced corn grain at levels up to $40 \%$ (DM basis). Dietary fat levels reached $6.3 \%$. Benson et al. (2005) reported a quadratic increase in DMI when corn DDGS replaced corn grain at levels up to $35 \%$ of the diet DM, with dietary fat levels reaching $7.3 \%$.

Differences in the energy content of the two cereal grains may account for differences in the DMI observed in finishing diets containing corn DDGS. Barley contains $1.40 \mathrm{Mcal} \mathrm{kg}{ }^{-1} \mathrm{NE}_{\mathrm{g}}$ whereas corn has 1.55 Mcal kg ${ }^{-1}$ of $\mathrm{NE}_{\mathrm{g}}$ (NRC 1996). In the present study, it is logical to assume that cattle fed ad libitum, the barleybased control diet were eating to meet their energy needs and thus were gaining at or close to their genetic potential. In this case, substituting corn DDGS with a higher $\mathrm{NE}_{\mathrm{g}}$ value for barley should result in reduced DMI, as observed (Table 2). In contrast, in studies where corn DDGS has replaced corn, differences in $\mathrm{NE}_{\mathrm{g}}$ content are not as great and thus large changes in DMI would not be expected.

As with wheat DDGS, there was no effect $(P=0.13)$ of corn DDGS inclusion level on ADG (Table 2). This is in contrast to Ham et al. (1994) and Buckner et al. (2008) who noted higher gains on cattle fed corn DDGS relative to those fed a corn-based ration. The lack of response in ADG is consistent with the reduced DMI of the corn DDGS fed cattle as discussed above. Cattle fed corn DDGS exhibited $(P<0.01)$ a quadratic increase in gain:feed $\quad\left(y=0.1564-0.0003 x+0.00003 x^{2} \quad R^{2}=0.95\right.$ SEP 0.004) with a local minima at the $4.6 \%$ inclusion level. These results support Larson et al. (1993) who reported cattle fed corn WDGS at $40 \%$ of the ration had a $20 \%$ improvement in gain:feed. Ham et al. (1994) also reported similar results for both corn WDGS and DDGS. Klopfenstein et al. (2008) in a meta-analysis of several studies utilizing corn DDGS up to $40 \%$ of the diet reported a cubic trend on gain:feed with optimal efficiency between 10 and $20 \%$ inclusion rates, while the $40 \%$ inclusion level had a calculated gain:feed similar to the control-based diets. In contrast to the results of the current study, Eun et al. (2009) reported no differences in gain:feed of cattle fed corn DDGS as a replacement for barley grain at levels up to $18.3 \%$ (DM), although corn DDGS inclusion resulted in a numeric improvement in gain:feed. The discrepancy between trials may arise from the higher inclusion level of corn DDGS in the present study, as the steers fed $20 \%$ corn DDGS in the present study had a gain:feed $(0.163$ vs. 0.162 , respectively) that was similar to those fed a diet with $18.3 \%$ corn DDGS (Eun et al. 2009).

The effects of corn DDGS on DMI and gain:feed is supported by the calculated $\mathrm{NE}_{\mathrm{g}}$ content of the diet (Table 2). The $\mathrm{NE}_{\mathrm{g}}$ content of corn DDGS rations increased $(P<0.01)$ in a quadratic fashion $(y=1.274-$ $0.0028 x+0.0003 x^{2} R^{2}=0.96$ SEP 0.029$)$ as corn DDGS inclusion level increased with a local minima at the 5.4\% inclusion level. The $\mathrm{NE}_{\mathrm{g}}$ content of the control diet was estimated to be 1.27 Mcal $\mathrm{kg}^{-1} \mathrm{NE}_{\mathrm{g}}$, while that of the $40 \%$ corn DDGS diet was estimated to be 1.58 Mcal kg-1 $\mathrm{NE}_{\mathrm{g}}$, an improvement of $24 \%$. Ham et al. (1994) reported a similar improvement $(21 \%)$ in $\mathrm{NE}_{\mathrm{g}}$ content of the diet when corn DDGS replaced corn grain at $40 \%$ of the ration. This increase in $\mathrm{NE}_{\mathrm{g}}$ content of the diet explains the reduction in DMI of the cattle fed $40 \%$ corn DDGS and the fact that gain was similar to the control-fed cattle. Predicted $\mathrm{NE}_{\mathrm{g}}$ daily intake was similar for the control and cattle fed $40 \%$ corn DDGS (13.2 vs. 13.9 Mcal, respectively). In contrast, there was no effect of wheat DDGS on calculated $\mathrm{NE}_{\mathrm{g}}$ content of the diet (Table 2).

USFAT and USLT gain measurements were not affected by treatment $(P>0.05)$ (Table 2). The lack of difference is likely a reflection of the similar $\mathrm{NE}_{\mathrm{g}}$ intakes amongst all diets $\left(13.5 \pm 0.3 \mathrm{Mcal} \mathrm{d}^{-1}\right)($ mean $\pm \mathrm{SD}$, DM) as well as the fact that the cattle were all taken to a common target weight at slaughter.

No effects $(P>0.05)$ of treatment were found on liver abscess scores (Table 3). Similar results were reported by Beliveau and McKinnon (2008) and Gibb et al. (2008). It has been proposed that adding DDGS to finishing diets would improve rumen $\mathrm{pH}$ due to the low starch and high fiber nature of the byproduct (Galyean and Defoor 2003; Klopfenstein et al. 2008). Beliveau and McKinnon (2009), however, reported that the addition of up to $21 \%$ wheat DDGS did not improve rumen $\mathrm{pH}$ relative to a barley-based control ration. These researchers attributed the lack of sub-acute ruminal acidosis mitigation to low levels of physically effective fiber and poor buffering capacity of DDGS. Furthermore, there was no difference in liver abscess scores between cattle fed corn and wheat DDGS (Table 3), and thus no evidence of a modulation influence on sub-acute ruminal acidosis as a result of the higher oil content of corn DDGS.

\section{Carcass Quality}

There was no effect of DDGS (wheat or corn) inclusion level on hot carcass weight $(P>0.54)$, estimated lean yield $(P>0.23)$, grade fat $(P=0.18)$ marbling scores 
Table 3. Effects of feeding wheat or corn dried distillers' grain with solubles (DDGS) at two inclusion levels on the carcass quality of finishing Cattle

\begin{tabular}{|c|c|c|c|c|c|c|c|c|c|c|c|}
\hline & \multicolumn{5}{|c|}{ Dietary treatment } & \multirow[b]{2}{*}{$\operatorname{PSEM}^{\mathbf{z}}$} & \multirow[b]{2}{*}{$\begin{array}{c}P \\
\text { value }\end{array}$} & \multicolumn{4}{|c|}{$P$ value contrast } \\
\hline & Control & $\begin{array}{l}20 \% \text { wheat } \\
\text { DDGS }\end{array}$ & $\begin{array}{l}40 \% \text { wheat } \\
\text { DDGS }\end{array}$ & $\begin{array}{c}20 \% \text { corn } \\
\text { DDGS }\end{array}$ & $\begin{array}{c}40 \% \text { corn } \\
\text { DDGS }\end{array}$ & & & $\begin{array}{l}\text { Linear } \\
\text { wheat }\end{array}$ & $\begin{array}{l}\text { Quadratic } \\
\text { wheat }\end{array}$ & $\begin{array}{l}\text { Linear } \\
\text { corn }\end{array}$ & $\begin{array}{c}\text { Quadratic } \\
\text { corn }\end{array}$ \\
\hline Shrunk ship weight $(\mathrm{kg})$ & 639 & 632 & 634 & 633 & 636 & 2.5 & 0.42 & & & & \\
\hline Hot carcass weight $(\mathrm{kg})$ & 371.9 & 370.8 & 374.8 & 375.3 & 375.6 & 5.34 & 0.54 & & & & \\
\hline Dressing percentage & 58.0 & 58.6 & 59.2 & 59.4 & 59.0 & 0.27 & 0.01 & $<0.01$ & 1.00 & 0.02 & 0.01 \\
\hline Grade fat $(\mathrm{mm})^{\mathrm{y}}$ & 7.8 & 8.2 & 9.0 & 8.2 & 9.0 & 0.41 & 0.18 & & & & \\
\hline Estimated lean yield $(\%)^{\mathrm{x}}$ & 61.2 & 60.6 & 59.8 & 60.6 & 60.0 & 0.45 & 0.23 & & & & \\
\hline L. thoracis area $\left(\mathrm{cm}^{2}\right)$ & 97.2 & 94.6 & 92.2 & 92.6 & 94.0 & 1.42 & 0.14 & & & & \\
\hline \multicolumn{12}{|l|}{ Marbling score ${ }^{w}$} \\
\hline Percentage with score 5 & 0.0 & 3.6 & 0.0 & 1.9 & 0.0 & 1.32 & 0.92 & & & & \\
\hline Percentage with score 6 & 5.5 & 0.0 & 0.0 & 1.9 & 0.0 & 1.39 & 0.57 & & & & \\
\hline Percentage with score 7 & 23.6 & 23.6 & 20.4 & 9.3 & 13.0 & 6.10 & 0.40 & & & & \\
\hline Percentage with score 8 & 58.2 & 50.9 & 66.7 & 79.6 & 74.1 & 7.24 & 0.09 & & & & \\
\hline Percentage with score 9 & 10.9 & 20.0 & 13.0 & 5.6 & 13.0 & 5.03 & 0.45 & & & & \\
\hline \multicolumn{12}{|l|}{ Liver abscess score $e^{\mathrm{v}}$} \\
\hline Percentage with score 0 & 67.3 & 56.4 & 66.7 & 61.1 & 61.1 & 7.22 & 0.81 & & & & \\
\hline Percentage with score 1 & 5.5 & 14.5 & 9.3 & 14.8 & 13.0 & 4.17 & 0.50 & & & & \\
\hline Percentage with score 2 & 16.4 & 7.3 & 7.4 & 13.0 & 9.3 & 3.51 & 0.34 & & & & \\
\hline Percentage with score 3 & 10.9 & 21.8 & 16.7 & 11.1 & 16.7 & 5.01 & 0.54 & & & & \\
\hline
\end{tabular}

${ }^{\mathbf{z}}$ PSEM $=$ pooled standard error of the mean.

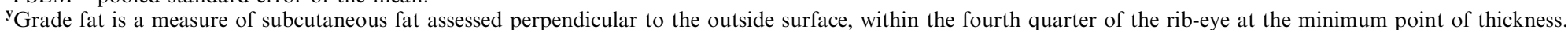

${ }^{\mathbf{x}}$ Estimated lean yield $=63.65+1.05$ (muscle score)- 0.76 (grade fat)

"Marbling score: $1=$ very abundant, $5=$ moderate, $6=$ modest, $7=$ small, $8=$ slight, $9=$ traces and $10=$ devoid.

"Liver abscess score: $0=$ no abscesses, $1=$ one small abscess $(\leq 1.25 \mathrm{~cm}), 2=$ two to four small to medium $(\leq 2.54 \mathrm{~cm})$ abscesses, $3=$ one or more large $(\geq 2.54 \mathrm{~cm})$ abscesses or greater than four small to medium abscesses. 
$(P=0.09$ to 0.92$)$ or 1 . thoracis area $(P=0.14)$ (Table 3$)$. However, dressing percentage linearly increased $(P<0.01)$ with inclusion level of wheat DDGS $\left(y=58.00+0.0300 x R^{2}=0.47\right.$ SEP 0.55). Beliveau and McKinnon (2008) also reported that wheat DDGS at levels up to $23 \%$ in finishing rations had no effect on estimated lean yield or marbling scores. Gibb et al. (2008) observed a quadratic decrease in subcutaneous fat thickness as well as a trend for reduced lean meat yield, but no effect on dressing percentage as wheat DDGS inclusion increased (up to 60\%) in finishing rations.

Dressing percentage increased $(P=0.01)$ in a quadratic fashion $\left(y=58.00+0.1150 x-0.0023 x^{2} R^{2}=0.50\right.$ SEP 0.658) as corn DDGS inclusion level increased in the ration with a local maxima at $26 \%$ (DM). Similar to the results of the present study, Benson et al. (2005) also found a positive linear effect of corn DDGS (up to $35 \%$, DM) on dressing percentage. The higher dressing percentage when feeding corn DDGS was attributed to an increase in subcutaneous fat and poorer yield grades (Benson et al. 2005; Eun et al. 2009). In the present study, wheat and corn DDGS at levels up to $40 \%$ (DM) had no effect $(P>0.05)$ on estimated lean yield or grade fat although estimated lean yield $(\%)$ decreased and grade fat increased numerically as DDGS (wheat and corn) increased (Table 3). In contrast, both Benson et al. (2005) and Eun et al. (2009) found yield grades to increase in response to greater inclusion levels of corn DDGS, again reflecting higher levels of subcutaneous carcass fat. The yields of sub-primal boneless boxed beef, trim and waste (fat and bone) were not affected by treatment $(P>0.05)$ (Table 4$)$, which is consistent with no differences in estimated lean yield and grade fat (Table 3). Data on meat quality from the 100 steers killed at Lacombe are reported by Aldai et al. (2009).

\section{CONCLUSION}

The results of this study indicate that feeding wheat DDGS in finishing rations up to $40 \%$ of the ration causes an increase in DMI and reduced days on feed. In contrast, supplementing corn DDGS for barley in finishing rations at levels up to $40 \%$ results in a decrease in DMI and an improved gain:feed. Furthermore, feeding corn DDGS increased dietary $\mathrm{NE}_{\mathrm{g}}$. Inclusion of wheat or corn DDGS did not impact marbling scores, hot carcass weight, estimated lean yield, grade fat or sub-primal boneless boxed beef. However, dressing percentage increased as both wheat and corn DDGS inclusion increased. Results from this trial indicate that both wheat and corn DDGS can be supplemented for barley in finishing diets at levels up to $40 \%$ with no negative impact on performance, carcass quality or subprimal boneless boxed beef yield. Cattle fed barleybased diets and supplemented with corn DDGS will exhibit improved gain:feed ratios due to decreased dry matter intake.

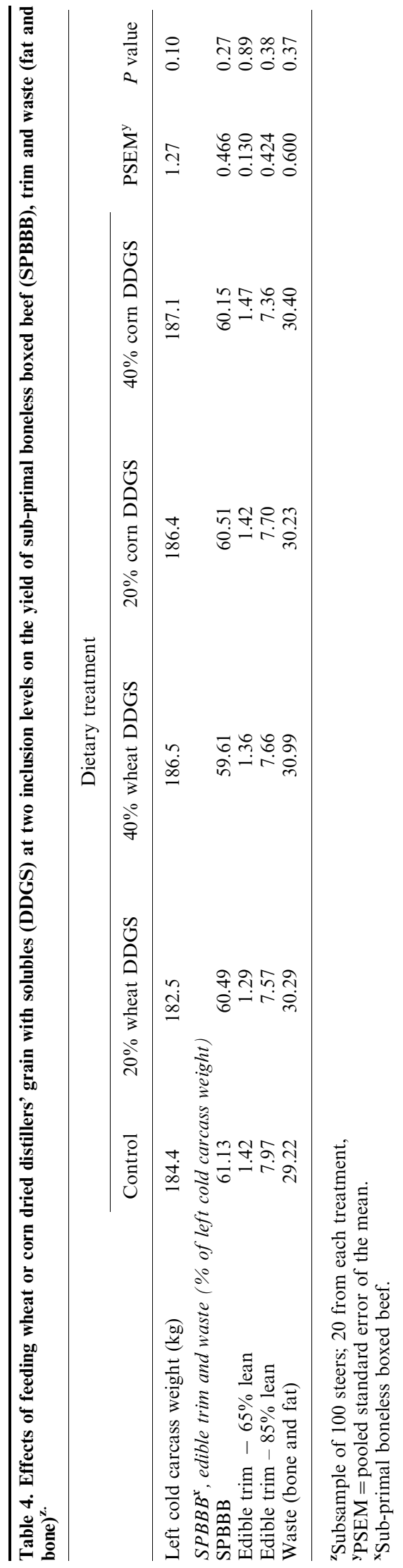




\section{ACKNOWLEDGEMENTS}

Gratitude is extended to Noramera BioEnergy Corporation of Weyburn, Saskatchewan, for supplying the wheat DDGS. Also, appreciation is expressed to the staff at the University of Saskatchewan Beef Cattle Research Station and the Lacombe Meat Research Centre for their assistance in conducting this research. Funding for this project was supplied by the following organizations: Advancing Canadian Agriculture and Agri-Food Saskatchewan, Beef Cattle Research Council, Alberta Cattle Producers, Agricultural Bioproducts Innovation Program, Canadian Wheat Board, National Science and Engineering Research Council and Saskatchewan Agriculture Development Fund. N. Aldai was supported by a research contract from the 7 th European Community Program (Marie Curie International Outgoing Fellowship, SPACANBEEF 220730).

Aldai, N., Aalhus, J. L., Dugan, M. E. R., Robertson, W. M., McAllister, T. A., Walter, L. J. and McKinnon, J. J. 2009. Comparison of wheat- versus corn-based dried distillers' grains with solubles on meat quality of feedlot cattle. Meat Science (in press).

Allen, M. S., Bradford, B. J. and Oba, M. 2009. The hepatic oxidation theory of the control of feed intake and its application to ruminants. J. Anim. Sci. 87: 3317-3334.

Association of Official Analytical Chemists. 2000. Official methods of analysis. 17ed. AOAC International, Gaithersburg, MD.

Beliveau, R. M. and McKinnon, J. J. 2008. Effect of titrated levels of wheat-based dried distillers grains with solubles on performance and carcass characteristics of feedlot steers. Can. J. Anim. Sci. 88: 677-684.

Beliveau, R. M. and McKinnon, J. J. 2009. Effect of graded levels of wheat-based dried distillers' grains with solubles on rumen fermentation in finishing cattle. Can. J. Anim. Sci. 89: 513-520.

Benson, C. S., Wright, C. L., Tjardes, K. E., Nicolai, R. E. and Rops, B. D. 2005. Effects of feeding varying concentrations of dry distiller's grains with solubles to finishing steers on feedlot performance, nutrient management and odorant emissions. South Dakota Beef Report. 2005-13: 59-67.

Bergen, R. D., McKinnon, J. J., Christensen, D. A., Kohle, N. and Belanger, A. 1997. Use of real-time ultrasound to evaluate live animal carcass traits in young performance-tested beef bulls. J. Anim. Sci. 75: 2300-2307.

Boila, R. J. and Ingalls, J. R. 1994. The post-ruminal digestion of dry matter, nitrogen and amino acids in wheat-based distillers' dried grains and canola meal. Anim. Feed Sci. Technol. 49: 173-188.

Buckner, C. D., Mader, T. L., Erickson, G. E., Colgan, S. L., Mark, D. R., Bremer, V. R., Karges, K. K. and Gibson, M. L. 2008. Evaluation of dry distillers grains plus solubles inclusion on performance and economics of finishing beef steers. The Professional Animal Scientist 24: 404-410.

Canadian Council on Animal Care. 1993. Guide to the care and use of experimental animals. Volume 1. E. D. Olfert, B. M. Cross, and A. A. McWilliam, eds. CCAC, Ottawa, ON.

Canadian Meat Council. 2000. Food service meat manual. 3 ed. CMC, Ottawa, ON.

Eun, J.-S., ZoBell, D. R. and Wiedmeier, R. D. 2009. Influence of replacing barley grain with corn-based dried distillers grains with solubles on production and carcass characteristics of growing and finishing beef steers. Anim. Feed Sci. Technol. 152: $72-80$.

Galyean, M. L. and Defoor, P. J. 2003. Effects of roughage source and level on intake by feedlot cattle. J. Anim. Sci. 81: $8-16$.

Gibb, D. J., Hao, X. and McAllister, T. A. 2008. Effect of dried distillers' grains from wheat on diet digestibility and performance in feedlot cattle. Can. J. Anim. Sci. 88: 659-665.

Gunn, P. J., Weaver, A. D., Lemenager, R. P., Gerrard, D. E., Claeys, M. C. and Lake, S. L. 2009. Effects of dietary fat and crude protein on feedlot performance, carcass characteristics, and meat quality in finishing steers fed differing levels of dried distillers grains with solubles. J. Anim. Sci. 87: 2882-2890.

Ham, G. A., Stock, R. A., Klopfenstein, T. J., Larson, E. M., Shain, D. H. and Huffman, R. P. 1994. Wet corn distillers byproducts compared with dried corn distillers grains with solubles as a source of protein and energy for ruminants. J. Anim. Sci. 72: 3246-3257.

Kleinschmit, D. H., Schingoethe, D. J., Kalscheur, K. F. and Hippen, A. R. 2006. Evaluation of various sources of corn dried distillers grains plus solubles for lactating dairy cattle. J. Dairy Sci. 89: 4784-4794.

Kleinschmit, D. H., Anderson, J. L., Schingoethe, D. J., Kalscheur, K. F. and Hippen, A. R. 2007. Ruminal and intestinal degradability of distiller's grains plus solubles varies by source. J. Dairy Sci. 90: 2909-2918.

Klopfenstein, T. 1996. Distiller's grains as an energy source and effect of drying on protein availability. Anim. Feed Sci. Technol. 60: 201-207.

Klopfenstein, T. J., Erikson, G. E. and Bremer, V. R. 2008. Board-invited review: Use of distillers byproducts in the beef cattle feeding industry. J. Anim. Sci. 86: 1223-1231.

Larson, E. M., Stock, R. A., Klopfenstein, T. J., Sindt, M. H. and Huffman, R. P. 1993. Feeding value of wet distillers byproducts for finishing ruminants. J. Anim. Sci. 71: 2228 2236.

McKinnon, J. J., Cohen, R. D. H., Kowalenko, W. S. and Janzen, E. D. 1992. The effects of feeding monensin and lasalocid together in the same diet or in a daily rotation program on performance and carcass characteristics of feedlot cattle. Can. J. Anim. Sci. 72: 273-278.

McKinnon, J. J. and Walker, A. M. 2008. Comparison of wheat-based dried distillers' grains with solubles to barley as an energy source for backgrounding cattle. Can. J. Anim. Sci. 88: $721-724$.

Nagaraja, T. G. and Chengappa, M. M. 1998. Liver abscesses in feedlot cattle: A review. J. Anim. Sci. 76: 287-298.

Nakamura, T., Klopfenstein, T. J., Gibb, D. J. and Britton, R. A. 1994. Growth efficiency and digestibility of heated protein fed to growing ruminants. J. Anim. Sci. 72: 774-782.

National Research Council. 2000. Nutrient requirements of beef cattle: Update. 7 th ed. National Academy Press, Washington, DC.

Reinhardt, C. D., DiCostanzo, A. and Milliken, G. 2007. Distillers byproducts alters carcass fat distribution of feedlot cattle. J. Anim. Sci. 85 (Suppl. 2): 132. (Abstr.)

Spiehs, M. J., Whitney, M. H. and Shurson, G. C. 2002. Nutrient database for distiller's dried grains with solubles produced from new ethanol plants in Minnesota and South Dakota. J Anim. Sci. 80: 2639-2645.

Van Soest, P. J., Robertson, J. B. and Lewis, B. A. 1991. Methods for dietary fiber, neutral detergent fiber and 
nonstarch polysaccharides in relation to animal nutrition. J. Dairy Sci. 74: 3583-3597.

Zinn, R. A. 1989. Influence of level and source of dietary fat on its comparative feeding value in finishing diets for steers: feedlot cattle growth and performance. J. Anim. Sci. 67: 1029-1037.
Zinn, R. A. and Shen, Y. 1998. An evaluation of ruminally degradable intake protein and metabolizable amino acid requirements of feedlot calves. J. Anim. Sci. 76: 1280-1289.

Zinn, R. A. and Jorquera, A. P. 2007. Feed value of supplemental fats used in feedlot cattle diets. Vet. Clin. Food Anim. 23: 247-268. 